Article

\title{
What Price Equality? The Academic Cost of Government Supervised Gender Mainstreaming at Swedish Universities
}

\author{
Erik J. Olsson ${ }^{1}$ and Jens Stilhoff Sörensen ${ }^{2, *}$ \\ 1 Department of Philosophy, Lund University, 22100 Lund, Sweden; erik_j.olsson@fil.lu.se \\ 2 School of Global Studies, University of Gothenburg, 40530 Gothenburg, Sweden \\ * Correspondence: jens.sorensen@globalstudies.gu.se
}

Received: 30 August 2020; Accepted: 29 October 2020; Published: 16 November 2020

check for updates

\begin{abstract}
This article is focused on gender mainstreaming at Swedish universities in the period from 2016-2019. Our research questions are: (a) In what form was gender mainstreaming introduced and did the form itself affect scholar's academic rights? (b) Was the process in question compatible with international standards of institutional autonomy? (c) What effect did gender mainstreaming have on scholars' ability to exercise their academic rights in accordance with international standards? Using the UNESCO Recommendations Concerning the Status of Higher-education Teaching Personnel (1997) as our international standard, we conclude that gender mainstreaming was introduced as a form of identity politics though government action and de facto supervision; that the latter was problematic from the perspective of institutional autonomy; that the choice of gender studies as a preferred scientific framework for university policy had a chilling effect on inquiry and free speech in other areas of research; and, finally, that gender mainstreaming led to violations of some scholars' individual rights. The findings may be taken into account in evaluations of the outcome of gender mainstreaming at Swedish universities, all things considered.
\end{abstract}

Keywords: gender mainstreaming; academic freedom; Lehrfreiheit; university autonomy; identity politics; Sweden; higher education; UNESCO

\section{Introduction}

As commonly understood, academic freedom is the freedom that researchers at institutions of higher learning have to pursue their own research questions in whatever direction they take them and communicate the results to whomever they want, provided they adhere to strict scientific and ethical standards. Academic freedom is believed to benefit not only universities themselves, but is also believed to be a common good which free societies have an interest in promoting and securing (UNESCO, 1997) [1]. At a general level, this paper addresses the extent to which academic freedom is compatible with a political movement referred to as "identity politics": a mobilization for a particular group in need of protection and support because it is considered to be disadvantaged or discriminated in some way. The protected group can, for instance, be a group of women that is commonly assumed to be suppressed and dominated by a group of men. In order to remedy this perceived state of affairs, various measures may be proposed. Our particular focus is on the introduction of one such measure-so-called gender mainstreaming - at Swedish universities in the period 2016-2019. There seem to be only two studies of this measure so far (both in Swedish). Jordansson and Peterson [2] focus on how the political directive was reflected in the universities' gender mainstreaming plans. Arpi and Wyndhamn [3], which is the work most similar to ours, addresses the effect of gender mainstreaming on scholarly work based on interviews. However, the authors do not relate their findings to particular academic principles relative to an international standard of academic freedom and university governance. 
Our specific research questions are: (a) In what form was gender mainstreaming introduced and did the form itself have consequences for scholars' academic rights relative to an international standard? (b) Was the process in question compatible with an international standard of institutional autonomy, a key ingredient in the concept of academic freedom aimed at protecting the political independence of universities? (c) What effect did gender mainstreaming, once introduced, have on scholars' ability to exercise their academic rights in accordance with an international standard?

The international standard will be the UNESCO recommendations concerning the status of higher-education teaching personnel (1997) (henceforth "the UNESCO recommendations") [1]. The recommendations allow for gender strategies under conditions that are spelled out in Article 41: "[t]emporary measures aimed at accelerating de facto equality for disadvantaged members of the academic community should not be considered discriminatory, provided that these measures are discontinued when the objectives of equality of opportunity and treatment have been achieved and systems are in place to ensure the continuance of equality of opportunity and treatment."

The motivation for studying in Sweden is that it is widely regarded one of the most successful countries when it comes gender equality, ranking as the fourth most gender egalitarian amongst 145 countries (World Economic Forum, 2015) [4]. Given that Sweden is seen as a role model in this particular regard, any development in Sweden is likely to affect the future of many countries [5]. It is therefore important to investigate the outcome of Swedish gender mainstreaming in academia. Here we focus on outcomes in terms of plausible violations of international norms regarding academic freedom as codified by UNESCO.

Section 2 introduces the concept of academic freedom and explains its standing in Western thought. Section 3 is an overview of the main ideas of identity politics and gender mainstreaming. How gender mainstreaming was introduced at Swedish universities as a particular kind of identity politics is the topic of Section 4. We present answers to our three research questions in Sections 5-7, respectively. We discuss our findings in Section 8 and reiterate our main conclusions in Section 9.

\section{Academic Freedom}

The idea of academic freedom runs deep in European intellectual history and is, at various stages, intimately connected to the scientific revolution, the Enlightenment and eventually the rise of democracy. This heritage is worth noting to show what is currently at stake with academic freedom. Having evolved over several hundred years a search for origins may be elusive but would probably place us somewhere in the European High Middle Ages. Walter Metzger has traced it to the Holy Roman Emperor Fredrick Barbarossa who in 1158 issued an edict to protect scholars [6,7]. It was then discovered as an important source during the scientific revolution when new observations and findings came in conflict with religious doctrine. While science for the most part coexisted harmoniously with the Church and sometimes was sponsored by it, and the scientists of the sixteenth and seventeenth century themselves held and respected religious beliefs, they sometimes clashed. The most famous case is Galileo Galilei's conflict with the Church over heliocentrism. The conflict between Martin Luther and the Catholic Church is another similar tension point in history, and provides the fore-runner to a rift between Catholics and Protestants, which is both an early form of identity politics (see Section 3) that led to civil and European wars, and the subsequent raw material for liberal toleration as a foundation for social peace [8]. ${ }^{1}$

While academic freedom is an elusive concept, just like sovereignty, liberty, or peace, it connects to a deep intellectual historical tradition and connects to other freedoms which are necessary for it to obtain meaning, such as freedom of speech [10]. Terrence Karran, following Neave, has noted the

1 Yet the tension between truth and power has a longer history, dating back to antiquity and the famous trial of Socrates who sacrificed his life for being a truth-teller. The role of truth-telling and speaking truth to power was a theme capturing the imagination of Michel Foucault who explored it in terms of its societal function since antiquity, which in Greek was called parrhesia [9]. 
variety of traditions in Europe, between the Italian medieval city republics with a prototype in Bologna, where autonomy was vested in the students who hired the professors, and Paris where autonomy was associated with the professor's freedom to teach $[7,11]$.

Over the past two hundred years, academic freedom has often been associated with the Humboldt tradition following the ideals of Wilhelm von Humboldt and the establishment of the Humboldt University in Berlin. While associated with Humboldt, the vision enshrined in the institution created was connected to a broader current in German society at the time. The ideal was both rooted in Enlightenment ideas of the individual and the world citizen and based on humanist tradition and took a holistic approach to education (Bildung) as an emancipatory and transformative process to become an autonomous individual. The double concept of Lehr-and Lernfreiheit captured both the teaching and learning side of the education process, with freedom for professors to teach according to their own best knowledge and design, and for students to freely choose and engage in their own studies. Today, it would mean that any external control over either side would violate the foundation of this process. Thus, for example, external pressure on teaching curricula or reading lists, or internal pressure for safe zones or de-platforming, would conflict with the scholar's freedom to teach or the student's freedom to learn by fully engage in the broad spectrum of ideas available. Other core freedoms include the freedom of inquiry and to select questions and methods for investigating them, as well as freedom to publish and engage in debate. Academic freedom also concerns institutional autonomy, such as the freedom to choose academic leadership, from institutional to university level. Moreover, academic freedom is dependent on a range of other freedoms, such as freedom of speech, and institutional and economic arrangements, such as tenure and research funding, without which academic freedom loses some of its meaning.

Many of these rights, in addition to obligations, can be found in the aforementioned UNESCO recommendations. Drawing on the European intellectual tradition and the Humboldt heritage, the recommendations are particularly aimed at protecting the autonomy of universities against political control. We will refer to the UNESCO recommendations below not only because they have been agreed upon by a majority of the UNESCO member states but also, and more importantly, because we believe that they provide a condensed and compelling formulation of the central elements of the Western tradition of academic freedom.

\section{Identity Politics and Gender Mainstreaming}

Threats to academic freedom potentially come from all interests that are not aimed at the pursuit of truth and knowledge. Apart from religious doctrine or political-ideological programs these interests may also be commercialization or short-term economic gain [12]. We can stipulate the three major sources of threats to academic freedom as being religious, political-ideological and commercial. Over times and places the source of the threat has varied. One such potential threat is identity politics. Although there is widespread attestation that identity politics is a new feature of contemporary politics, there is no general consensus on how do define it, partly because it is difficult to pin down what is meant by 'identity' [13]. It is even questionable whether there is any particular productive tension in the literature with its diversity ranging from the activist to the ontological, addressing such issues as what constitutes the self, authenticity and the social construction of identity [14-16].

One way to tentatively define identity politics is as a political mobilization and organization for a particular interest or a group interest (as opposed to public interest), where the group is founded or rests upon identity based upon race, ethnicity, sex or religion. ${ }^{2}$ A core tenet is that the group is considered to be disadvantaged or discriminated in some way in society. Another central belief is that

2 Compare the Merrian-Webster Dictionary [17] which defines identity politics fairly similarly as: "politics in which groups of people having a particular racial, religious, ethnic, social, or cultural identity tend to promote their own specific interests or concerns without regard to the interests or concerns of any larger political group". 
equal opportunity is not sufficient, but there is a request for equal outcome, often through quotas and affirmative action.

Yet it is crucial to not subsume all and every mobilization of a group based upon group identity under identity politics. ${ }^{3}$ For example, the civil movement in America during the 1960s is sometimes characterised or portrayed as identity politics, whereas in fact it made claims about universal and equal opportunity rather than outcome based upon identity. Martin Luther King's famous speech includes the words "I have a dream that one day my four little children will ... not be judged by the colour of their skin but by the content of their character" (Martin Luther King, speech 28 August 1963 in front of the Lincoln monument). These claims are consistent with the liberal idea of equality. While liberalism is a broad tradition with a range of conflicting formulations and practices on equality, there is a general social ontology that views all individuals as essentially similar in those aspects that pertain to them as political subjects. ${ }^{4}$ Another example which may serve to delineate identity politics is the working class' movement and its organization. Here too the general claim was about equality understood in terms of opportunity. The Social Democratic welfare state in Scandinavia, arguably where the working class' movement achieved its best representation in the post-war democratic world, made explicit claims about equal opportunity, but never equal outcome. The Swedish Social Democratic Prime Minister Olof Palme spoke of how "class solidarity became social solidarity" (or civic solidarity) [20].

The upshot is that we should reserve the term identity politics for requests for outcome or representation based upon identity. When equality is conceived of as equal outcome, by means of representation or quotas based upon group identity, there is a qualitative move. The individual is now placed in a category based upon group identity. This is a form of tribalism where the individual becomes subjugated to the category.

The idea of intersectionality is a further important component of identity politics, as an account of various kinds of discrimination and power relations. It was developed during the 1970s and 1980s by Afro-American feminists and activists who criticized the Women's movement of the time for not seeing, understanding and taking in account issues facing black women, but also more generally for misunderstanding repression. Racism, sexism and other forms of discrimination, they claimed, are not separate phenomena but are connected and overlapping and form a network or matrix of crossing or intersecting privileges and repression or discrimination. This means one can be privileged on one parameter (for example male) and discriminated on another (for example black). The parameters and categories can here be multiplied infinitely.

There is but a small step from intersectionality to far-reaching relativism. For example, according to Andersen and Collins [21], dominant narratives in science have been created by privileged groups, and objectivity is Western and masculine. An important task, in their view, is to bring forward deeper truths which subjugated groups are assumed to have access to but which individuals not belonging to these groups cannot fully entertain or criticize. The position becomes relativistic to the extent that it entails that there is no inter-subjective truth, only various subject positions, perceptions and opinions.

Turning to gender mainstreaming, underlying the various accounts are different models of gender equality, including prominently models based on identity [22]. On one influential account, gender mainstreaming is "a strategy that claims to make women's and men's experiences an integral dimension in the design, implementation, monitoring and evaluation of policies and programs" [23] (p. 609).

3 This is sometimes the case, but the definition then becomes so broad as to include various movements where identity is somehow assumed to be a key ingredient. But since identity to some degree and in some regard is almost always included in all social movements, be it working class movement, football clubs, nudists or vegans, it would be too broad a definition to make it an operationalizable concept for our purposes. For such broader definitions, see for example [18].

4 An example is John Rawls hypothetical model of an original position with a "veil of ignorance" behind which subjects make decisions about a social contract [19]. An idea here for constructing just societies is that you may choose which kind of society we shall have if you then allow me to choose your position in it. In this experiment all individuals or political subjects are conceptualized as essentially similar, devoid of special interests or identities with regard to their position as political subjects. The Anglophone liberal tradition from Locke to Mill likewise presupposes a social ontology of similar individuals, which is expresses in the American Declaration of Independence as "all men are created equal". 
As such, it is usually seen as a third wave of reform and more radical, in the sense of transformative, than the two earlier strategies of either (a) inclusion through equal opportunity or (b) recruitment and selection through affirmative action (reversal, or positive action) (cf. Bacchi [24], who, however, argues against a necessary dichotomy between these strategies).

Gender mainstreaming originates from feminist theory and first made its inroad in development studies and international aid policy but has also become adopted by the European Union [23]. Many international organizations have produced guides with toolkits of measures to implement gender mainstreaming (i.e., Council of Europe, Commonwealth Secretariat, UNDP, UNESCO and Bureau for Gender Equality) [25-29]. Gender mainstreaming aims to transform the state machinery and measures may range from changes in agenda setting to representation. Within higher education, it can, for example, involve changes in curriculum, course content, staffing, planning, representation and learning environment $[23,29]$.

Since gender mainstreaming is a strategy, we may ask about the outcome of a particular implementation. Here, there is a range of problems, both in terms of how to evaluate outcomes that may differ considerably depending on context, and how the measures are perceived and conceived [23]. According to Charlesworth [30], there has been little work to measure the progress of gender mainstreaming. In the following, we analyze specifically the outcome of gender mainstreaming in Swedish higher education 2017-2019 vis-à-vis academic freedom. Our methodology consists of analysis of publicly available documents from the Swedish government and Swedish universities, informed by relevant scholarly and journalistic work, and of publicly documented case studies from an independent NGO, and comparison of the result of this analysis with relevant articles in the UNESCO recommendations [1].

\section{The Introduction of Gender Mainstreaming in Swedish Universities}

Based on a decision from 2015, the government declared in a decree from 2016 ("regleringsbrev") that all Swedish state universities should "develop a plan for how the university intends to develop the work on gender mainstreaming in order that the activities will contribute to attaining the equality goals" [31]. The latter concern included "equal opportunities to career paths, gender stereotypical educational choices and throughput". It is added that "universities and university colleges ("högskolor") may in their work with gender mainstreaming call on support from the University of Gothenburg". As part of the strategy, the government announced the goal of establishing an even gender balance among professors; in 2030, 50\% of all recruited professors at Swedish universities should be women. Then Minister for Research and Higher Education Helene Hellmark Knutsson explained the motivation for this decision on the government's homepage ([32], our translation):

If Sweden wants to be a prominent knowledge and research nation, we must have a more equal university. It is for example a waste of the available competence that so few women become professors. I am convinced that if universities and university colleges would employ a gender mainstreaming method, this is a step toward a more equal university.

This passage is in important respects ambiguous. The first sentence is neutral between the "equal opportunity" and "equal outcome" reading of "equal". The second statement, however, suggests that it is about attaining (a more) equal outcome, which would place the statement in the identity-political genre. Even so, the second statement also proposes that (a more) equal outcome regarding the gender of professors would contribute to the collective competence of academia, which qualifies as a public good. If so, the motivation for the goal of attaining (a more) equal outcome is not, or not only, about protecting the group of women per se and securing a more equal distribution of power between the sexes; it is also about promoting academic excellence.

At this time, all other state authorities had already gone through the process of gender mainstreaming with the support of the Swedish Secretariat for Gender Research at the University of Gothenburg. When now the turn had come for universities to become gender mainstreamed, 
the Secretariat was once more instructed by the government to lead the process. The Secretariat describes its history and role as follows on its English homepage [33]:

The secretariat has been a national unit, sited by the Ministry of Education at the University of Gothenburg, since 1998, with a mission to promote gender research in Sweden in the university and higher education sector. Over time, a range of new commissioned work and a greater collaborative role have seen us develop into a knowledge hub. The secretariat reports to the Vice Chancellor and networks with the other national units hosted by the university. Our work is headed by a Director and a Deputy Director who jointly decide on the way work is conducted and allocate tasks and roles. Drawing on international research on gender, power and sustainability, the secretariat uses and develops different scientific perspectives and methods in its operations. Working with other researchers and expert organisations strengthens our collaboration, communication and production of knowledge.

It is noteworthy that the Secretariat is both an academic research division at the University of Gothenburg and at the same time a "national unit" with a stated "mission to promote gender research in Sweden in the university and higher education sector".

Where the Minister had been vague regarding the true motivation behind gender mainstreaming at universities, the Secretariat is much clearer and, as we will see, also more radical and transformational. After noting the rather unspectacular goals listed in the government's decision, focusing on equal rights and opportunities of men and women, the Secretariat adds in its instructions to universities ([34], p. 6, our translation):

It is important that the work to attain equality is based on an in-depth understanding of what sexed inequalities should be counteracted. Carefully defined problems create the preconditions for taking the right measures and achieve results with gender mainstreaming as strategy.

At the same time, women and men are not two homogeneous groups. Class in terms of socio-economical background and educational level, as well as ethnic identity and/or skin colour, contribute to differences both within and between the categories of women and men. Sexual orientation, age and handicap are other power structures which similarly great heterogeneity. Moreover, not all human beings either can or want to identify themselves as women or men. If the analyses are coupled too much to the categories "women" and "men," simplified assumptions are often recreated rather than challenged.

For gender mainstreaming to contribute to change it is therefore necessary to broaden the understanding of how sex co-varies with other power structures. The concepts of equality and inequality include all the power structures in these guidelines. When the concept of gender is used it is, similarly, to show the need for a critical power analysis of how sex is made in relation to other power structures.

These passages are immediately followed by a reference to another guideline called "Gender mainstreaming with intersectional perspective".

While the original governmental equality goals allow for the interpretation that it is about equal rights and opportunities of men and women, the Secretariat's "in-depth understanding" adds several ideas from the identity-political tradition. One is that equality is more than just equality between women and men since some individuals may not identify as either, a remark that is followed by the related claim that "sex is made", that is, constructed rather than biologically given. Finally, the goals should, according to the Secretariat, be attained by focusing on all power structures and not just power structures related to sex or gender. This is a striking re-interpretation of the government's 2015 decision. It is also more clearly identity-political than the statement of Minister, who, as we 
saw, seemed to suggest that a more equal gender distribution among professors would contribute to academic competence. No clear connection is made between gender mainstreaming and academic competence, e.g., to the effect that the former would promote the latter. ${ }^{5}$

During the period in which the Secretariat acted as a national support function for all universities in Sweden, it organized network meetings for the leadership groups from these institutions. The universities were to write plans based on material from the Secretariat whose employees return them with comments to the university leadership. The plans were then revised locally, taking comments and proposals from the Secretariat into account. After a formal decision by the university to accept the final version of the plan, it was sent to the Secretariat, which in turn reported to the Department of Education ([3], p. 81).

Hence, until the Swedish Gender Equality Agency was created in 2018 and then took over the responsibility as a support function for gender mainstreaming, the role played by the Swedish Secretariat for Gender Research was central in the process of implementing the policy at Swedish universities. Pedagogy lecturer Anna-Karin Wyndhamn, who worked at the Secretariat at the time, recently published notes that she took in the Spring of 2017 in which she reflects on her work in the Secretariat [3]. As she sees it, the employees at the Secretariat were instructed to "correct" the universities' gender mainstreaming plans if the intersectional perspective was missing (ibid., pp. 83-85). Wyndhamn recorded what happened when one university presents a plan that was not clearly intersectional (ibid., pp. 85-86):

I obstruct against the agreed working model and engage loosely with the extremely detailed reading instructions ... I sat as it happened with Malmö's plan [the plan from Malmö University]. They start by referring to Yvonne Hirdman. Suddenly I woke up when reading. Hirdman's gender construction is viewed at the Secretariat as an antiquated analysis model because it is not sufficiently intersectional, and we prefer not to mention her. Malmö's statement invites me to do the same. Generally my autonomy is not in good shape right now. To tease, I wrote an comment in which I in a merry tone complemented the university for its autonomous perspective. Autonomous, that is, relative to the Secretariat ... Colleagues reject the plan because a Hirdmanian view keeps focus on the relation between the sexes, it does not dissolve the sex categories. It is primarily with the latter we should provide support and I have more and more trouble with this. It is not my mission.

Of course, Wyndhamn was just one among many employees at the Secretariat involved in gender mainstreaming and we do not claim that her view of the general direction of the work at the Secretariat is representative. ${ }^{6}$

\section{In What form Was Gender Mainstreaming Introduced?}

We now turn to our first research question: In what form was gender mainstreaming introduced? In their overview of the universities' gender mainstreaming plans [2], Jordansson and Peterson found that, while the final plans submitted by the universities differ in emphasis, most contain analyses that identify women as disadvantaged and focus on policies focusing on changing power structures to protect and support women in academia, often alongside policies motivated by the legal requirement of equal opportunity in the Discrimination Act. For instance, Malmö University's final plan contains five occurrences of (the Swedish word for) "intersectionality", ten occurrences of (the Swedish word

5 The (Swedish word for) competence occurs ten times in the Secretariat's instructions. However, five occurrences are about competence in gender mainstreaming and not general academic competence in research or teaching.

6 In a published interview [35], Wyndhamn describes how she was inspired by Jordan B. Peterson to come forward and voice criticism against the way in which gender equality was pursued at her workplace, even if it would mean that she would lose her job. Eventually, she decided to resign from her appointment at the Secretariat. 
for) "power" and among the latter eight occurrences of (the Swedish word for) "power structure". The document also contains criticism of "masculinity" and "male privilege" ([36], p. 8, our translation):

This form of masculinity and competition which characterizes power structures in the academy risks among other things creating research in which the problem formulation becomes a male privilege and norm. This normalisation of the masculine, allegedly gender neutral and "objective" making other perspectives invisible.

Our second example will be Lund University, the second oldest in Sweden after Uppsala University, which adopted its gender mainstreaming plan in May, 2017 [37]. We will dwell on Lund University's plan because it provides a background to our two case studies of interference in scholars' rights due to gender mainstreaming. Both cases played out in Lund and in one case, the case of Germund Hesslow, the Human Resource official behind the eventual discrimination report was also a member of the smaller committee which presented the plan to the Vice Chancellor for the final decision, and she also co-signed the plan with him.

Gender mainstreaming is defined in the plan as the "(re)organization, improvement, development and evaluation of policy processes, so that a gender equality perspective is incorporated in all policies at all levels at all stages, by the actors involved in policy-making" (ibid., p. 3). The plan explains that "gender equality means that women and men have the same opportunities, rights and obligations". This would suggest a focus on meritocratic hiring and elimination of discriminatory elements in the hiring process. However, what is actually proposed is more far-reaching, namely that "[g]ender equality can be achieved by working with long-term qualitative measures for changing the structure, power and culture within an organization" (ibid, p. 3). It is added that "[t]he qualitative change is expected to also bring about a quantitative change" (ibid, p. 3). The document proceeds to expand on the latter statement:

In recent years, the University's goals for gender equality management have tended to be quantitative, linked to the reporting requirements included in the public service agreement. The quantitative goals remain, but the gender mainstreaming task opens up for a more qualitative perspective, in which a change in culture and in the division of power are contributing factors.

Exactly how this "change in culture and in the division of power" should be implemented is not explained in concrete terms, save that a "gender equality and diversity perspective" should be established in the recruitment of staff as well as of students.

The university observes that there is an uneven gender balance not only among the academic staff, mainly the professors, but also among the administrative staff, which is dominated by females. A critic might think that this may simply be a matter of men and women on average having somewhat different interests where women are on average more interested in working with people rather than, say, spending day alone in the laboratory studying some bacteria or at the desk proving a theorem [38,39]. However, this alternative explanation is not considered by the university, which-in line with the theory of intersectionality promoted by the Secretariat-views the uneven gender balances in the academic and administrative parts as a symptom of a hypothesized underlying inequality in power ([37], p. 5):

There is an uneven gender balance among staff, which may adversely affect women's and men's opportunities and rights within the organisation. For example, there is a dominance of women in the administrative staff category, which is usually classified as having a support function, while there is a dominance of men in the senior teaching staff category, which is classified as having a core or leadership function at the University.

Hence, since men are dominating in the academic "leadership" function and women in the administrative "support" function, the assumption is that men are currently exerting (illegitimate) power over women. 
As hinted above, however important, the gender studies perspective on sex and equality upon which universities will now base various decisions, including the hiring of academic staff, is not the only perspective on sex and equality pursued in science. A number of other disciplines study sex differences e.g., from a biological perspective. For example, an overview of sex differences in science and mathematics found that males are consistently overrepresented among both overachievers and underachievers [40]. The study concluded that "early experience, biological factors, educational policy, and cultural context affect the number of women and men who pursue advanced study in science and math and that these effects add and interact in complex ways" (p. 1), in which case "[t]here are no single or simple answers to the complex questions about sex differences in science and mathematics" (ibid.).

Thus, a purely social or power perspective on sex differences is insufficient to explain empirical data, and yet gender mainstreaming based solely on work in gender studies does not seem to allow for biological sex differences. This gives rise to a tension between gender mainstreaming in the present form and one of the guiding principles in the UNESCO recommendations [1]:

Institutions of higher education, and more particularly universities, are communities of scholars preserving, disseminating and expressing freely their opinions on traditional knowledge and culture, and pursuing new knowledge without constriction by prescribed doctrines. The pursuit of new knowledge and its application lie at the heart of the mandate of such institutions of higher education.

The risk, if gender mainstreaming implies that biological perspectives on sex differences are excluded from the outset already by university policy, is that scientists working within biological research paradigms cannot pursue new knowledge without constriction by prescribed (gender) doctrines, or express freely their opinion on biological matters, without being subjected to administrative or other sanctions. As will be clear from the case studies in Section 7 (the Hesslow case), this risk is not merely a theoretical possibility but in fact quite real.

\section{Was Institutional Autonomy Violated?}

The task of supporting Swedish universities in their developments of plans for gender mainstreaming was assigned, as we saw, to the Swedish Secretariat for Gender Research, which at the same time was, and still is, a research unit within the University of Gothenburg, thus acting as a governmental "Trojan horse" in the academic system. The detailed testimony of then member of the Secretariat Anna-Karin Wyndhamn [3] suggests that the "support" often meant influencing the universities so that they would include not only efforts to increase the importance of meritocracy in recruitments etc. but also endorsements of intersectionality and a focus on the power structures giving rise to what the Secretariat takes to be power inequalities. Thus, the suspicion arises that there is a problem of institutional autonomy lurking in the way in which Sweden implemented gender mainstreaming.

The UNESCO recommendations highlight the importance of institutional autonomy for academic freedom, the former being defined in Article 17:

The proper enjoyment of academic freedom and compliance with the duties and responsibilities listed below require the autonomy of institutions of higher education. Autonomy is that degree of self-governance necessary for effective decision making by institutions of higher education regarding their academic work, standards, management and related activities consistent with systems of public accountability, especially in respect of funding provided by the state, and respect for academic freedom and human rights. However, the nature of institutional autonomy may differ according to the type of establishment involved.

According to Article 18, "[a]utonomy is the institutional form of academic freedom and a necessary precondition to guarantee the proper fulfilment of the functions entrusted to higher-education 
teaching personnel and institutions". Article 19 adds that "[m]ember States are under an obligation to protect higher education institutions from threats to their autonomy coming from any source". Finally, the importance of self-governance and collegiality are highlighted in Article 21: "Self-governance, collegiality and appropriate academic leadership are essential components of meaningful autonomy for institutions of higher education."

Collegiality and self-governance certainly played a role in how some Swedish universities developed their gender mainstreaming plans. For instance, at Lund University all faculties were involved in the deliberation process, although, as we noted, the HR department played a special role. In other cases, the operative responsibility for the plans was delegated to the HR department, with less influence from the academic part of the university [2]. However, given its special status as a national unit with a particular government mission to support the universities in their gender mainstreaming activities, the involvement of the National Secretariat for Gender Research itself represented a direct threat to the autonomy of Swedish universities, quite independently of the actual effect this involvement had on the final plans. The perception is that the Secretariat acted as a governmental agent to impose the politically preferred gender studies perspective on sex and gender on the universities, in contrast to more biologically oriented perspectives. In addition, the evidence presented above, e.g., in the form of special instructions produced by the Secretariat, indicates that this involvement was not without effect, but that it led to a radicalization of the plans in the direction of identity politics and intersectional analysis.

An important corollary of article 19 is that member states are under an obligation to protect higher education institutions from threats to their autonomy coming from the government itself. Our analysis vis-à-vis autonomy suggests that the Swedish government, in its efforts to introduce gender mainstreaming at all universities, failed to protect universities precisely from the threat to their autonomy coming from the government itself and, in particular, from the Ministry of Education and the Ministry-associated Swedish Secretariat of Gender Research.

\section{Did Gender Mainstreaming Lead to Violation of Academic Rights?}

The following two case studies which were first documented by Academic Rights Watch, an independent academic watchdog with representatives at several Swedish universities, indicate how scholars' freedom to teach (Lehrfreiheit) was plausibly compromised, by international standards, as the effect of the introduction of gender mainstreaming at the university in question. ${ }^{7}$ The two cases are plausibly the best documented such cases and have received the most attention from the public and the media. 8

In September 2018, Academic Rights Watch reported on the case of Germund Hesslow (at the time Professor of Neurophysiology and Associate Professor of Philosophy at Lund University) [41], whose lectures on "Heritage and Environment" was criticized by a student for being in possible violation of the university's discrimination and equal treatment policies, i.e., policies derived from Lund University's gender mainstreaming plan. ${ }^{9}$ Following the criticism, the Chairman of the medical

7 Both Germund Hesslow and Erik Ringmar, the main character in the second case study, have commented on their respective cases publicly, which is why they are mentioned here by name. The Hesslow case is described here in greater details as it is relevant to two of our research questions, namely (a) and (c) (see the introduction); the Ringmar case is relevant to just one research question, namely (c).

8 For a case at Swedish University of Arts, Crafts and Design see https://academicrightswatch.com/?p=2855. It was required of successful applicants for a professorship that they had exercised "norm criticism" in their previous artistic work. A norm critical approach involves, according to a reviewer, "a sustained, rigorous critique of cultures, systems and institutions that marginalize, oppress and enact violence upon a range of subjects occupying subaltern socio-political positions". By contrast, Article 47 (b) in the UNESCO recommendations prescribe that evaluation of scholars be "based only on academic criteria of competence in research, teaching and other academic or professional duties as interpreted by academic peers".

9 The case closely parallels the well-known controversy between the Canadian psychology professor Jordan B. Peterson and the Canadian state regarding the mandatory use of certain gender pronouns (Bill C-16). 
program urged Hesslow to apologize for certain formulations regarding homosexuals and transsexuals, which he refused to do.

Following the accusations, the leadership decided to open an internal investigation into charges of discrimination and harassment. While the investigation acquitted Hesslow of any wrongdoing, it also states that there is nevertheless "risk for discrimination". Its recommendation is that the Faculty should take the actions it deems necessary to reduce this risk. As we mentioned before, the person in charge of the investigation also played a central role in the development of Lund University's gender mainstreaming plan.

In a commentary, Professor Hesslow denounced the decision to open a formal investigation in the first place. He wrote: "Each one who in the future considers lecturing about subjects that can cause strong emotions or saying things that some students wouldn't wish to hear now has to consider the possibility of being subjected to considerable discomfort and public investigation using completely different standards than those usually applied when evaluating lectures" (our translations throughout).

In a letter to Hesslow, the Faculty Dean reports a number of new gender strategies introduced by the Faculty. Among them are certain terminological requirements: "With regard to the criticized lecture, the program management has already informed you of the correct terminology regarding gender identity and sexual orientation". Furthermore, "[i]n order to broaden the perspective, your lecture will also be supplemented with a lecture on perspectives on sex and gender in medical science". The Faculty Dean's reference to the "correct terminology" refers to Hesslow's claims (made in passing in response to a student question in the Q\&A section) that "homosexual women have a male sexual orientation" and, with regard to transsexuality, that "whether it's a sexual orientation is a question of definition".

These formulations were criticized by the program Chairman for not respecting "the terminology as defined in Swedish law", with reference to the Swedish Discrimination Act. Regarding transsexuality it is worth noting that according to the Discrimination Act (2008: 567) it is not a sexual orientation. Sexual orientation is described as "homosexual, bisexual or heterosexual orientation" (Ch. 1, §5). Hesslow explained, in a written response to the student, that his statement alluded to the fact that there are, in his view, scientific grounds to believe that "it is not possible to draw any strict borders between transsexuality/gender dysphoria and homosexuality".

As Academic Rights Watch notices, one might question the academic merit in thinking that the Discrimination Act or any other law enacted by the Swedish people's representatives in the parliament as the expression of the will of the majority, should determine which terminology a professor should use in his lectures on the biological basis for sex differences. The very motivation for academic freedom is that science and scientific discourse are not slaves to public opinion but should be allowed to contradict beliefs commonly held, something which may lead to a correction of the latter to the benefit of society at large. Objecting to Hesslow's scientific conclusions on the grounds that they fail to comply with current legal terminology is, from this perspective, a symptom of an academic failure. ${ }^{10}$

Other gender directives to be introduced are a new seminar series "with focus on the grounds of discrimination which are introduced by the theme of trans-persons' encounter with health care" and a mentor program for senior researchers which will "focus on gender". Within the research program there are, the Faculty Dean continues, "courses with focus on gender and intersectionality perspectives on medical research". "As a further measure the management for the faculty education program will, aided by tools developed by section Personnel at Lund University, work to identify what risks there are within the programme". This will lead to further plans of action, and so on.

Hesslow's actions are unsurprisingly protected by several articles in the UNESCO recommendations so that the question must be raised whether the corresponding rights have been violated by his university. As we saw, one of the guiding principles states:

10 The Discrimination Act is irrelevant in this context for another reason as well. It says nothing about the causes or orientation of female homosexuality. For example, it says nothing about whether or not homosexual females have a male sexual orientation. 
Institutions of higher education, and more particularly universities, are communities of scholars preserving, disseminating and expressing freely their opinions on traditional knowledge and culture, and pursuing new knowledge without constriction by prescribed doctrines. The pursuit of new knowledge and its application lie at the heart of the mandate of such institutions of higher education.

When Hesslow freely expressed his opinions, his right to free speech was not protected by the university, which instead decided to investigate him for possible discrimination. Moreover, the university interfered in Hesslow's teaching, in contrast to the academic norms spelled out in Article 27:

Higher-education teaching personnel are entitled to the maintaining of academic freedom, that is to say, the right, without constriction by prescribed doctrine, to freedom of teaching and discussion, freedom in carrying out research and disseminating and publishing the results thereof, freedom to express freely their opinion about the institution or system in which they work, freedom from institutional censorship and freedom to participate in professional or representative academic bodies.

Hesslow can hardly been said to have been in a position to enjoy "freedom from institutional censorship"; on the contrary, his institution has required of him a particular way of speaking and his loyalty to a particular "prescribed [gender] doctrine". The norms constituting the fundamental academic principle of Lehrfreiheit are laid out in Article 28:

Higher-education teaching personnel have the right to teach without any interference, subject to accepted professional principles including professional responsibility and intellectual rigour with regard to standards and methods of teaching. Higher-education teaching personnel should not be forced to instruct against their own best knowledge and conscience or be forced to use curricula and methods contrary to national and international human rights standards. Higher education teaching personnel should play a significant role in determining the curriculum.

Plausibly, Hesslow was not granted the privilege of teaching "without any interference", but his attempt to do so led, again, to him being subjected to a formal investigation into alleged discrimination. It is true that Hesslow has lately been allowed to give his lecture in its original form, but his authority has been undermined by the perceived necessity to have a supplementary lecture held by another teacher on perspectives on gender in medical science.

In another case also reported by Academic Rights Watch, Erik Ringmar, at the time a lecturer in Political Science at Lund University, decided to cancel his course on the modern history of conservative and fascist thought [42]. This was after the department introduced a rule that forces teachers to use gender quotas for course literature where at least $40 \%$ of the literature should be written by female authors. As in Hesslow's case, the department's policy in this matter is based on Lund University's gender mainstreaming plan.

The intention was that the course should be based on conservative primary literature from late 1800 and early 1900. Ringmar, however, was reportedly not able to find enough female conservative writers to fill the $40 \%$ quota. In the end, he managed to find a female writer who opposed women's suffrage. However, the Director of Studies judged that the course would still not be approved by the department's literature committee, and, indeed, a student representative subsequently criticized it for lack of focus on gender. A compromise was reached to the effect that the course would be approved if Ringmar promised to include a work by Judith Butler, a feminist writer in the poststructuralist tradition.

Yet, when the course started, Ringmar choose to leave out Butler on grounds of irrelevance. This decision led some students to complain to the Department Dean, this time because the course did not comply with the reading list. At that point, Ringmar decided to cancel the course. The Department's treatment of Erik Ringmar is a further example of how teachers are "forced to instruct against their 
own best knowledge and conscience" as the effect of gender mainstreaming, in violation of the aforementioned Article 28 of the UNESCO recommendations. ${ }^{11}$

\section{Discussion}

Why did the Vice Chancellors of Swedish universities not generally reject gender mainstreaming in the radical form promoted by the Secretariat, given that the risks in relation to academic freedom could hardly have gone unnoticed? One factor is that contrary to the practice in many other European countries, Swedish Vice Chancellors and the Chairman and external members of the university board are appointed by the government [44]. In the European University Association's (EUA) university autonomy scorecard (updated 2016), Sweden receives the lowest possible score for the appointment of the Vice Chancellor [45]. Overall, EUA ranks the organizational autonomy of Swedish universities at position 19 in a European perspective, after Poland but before Hungary. Universities in the UK receive the highest score on this dimension. Thus, there are structural features of Swedish higher education that may have a chilling effect on Vice Chancellors' willingness to speak up against the government's will. $^{12}$

Relatedly, it might be asked how it is at all legally possible that government policy is implemented in Sweden through an academic division that plays the double role of a governmentally installed national unit. As part of the answer, Karran et al. [47] found that Sweden was among the lowest scoring countries in Europa regarding the overall legal protection of academic freedom, with particularly low scores for legal protection of institutional autonomy and self-governance, the two aspects of academic freedom whose very purpose is to protect academia from politicization through government intervention.

The question arises as to whether the Swedish Secretariat for Gender Research acted on its own behalf when it contributed to the introduction and establishment of a radical transformative identity-political version of gender mainstreaming at Swedish universities. Alternatively, the Secretariat was part of a plot carried out by activist government members to introduce, at lower levels of the governmental hierarchy, a more radical form of gender policy than the government would actually support. It is noteworthy that the Deputy Director at the time who wrote a doctoral thesis on equality in higher education in 2004 in the post-structural tradition and is identified in Arpi and Wyndhamn (2020) as the driving force behind the Secretariat's radicalism [3], before he came to the Secretariat was a member of the expert committee for equality in the academy (DEJA) headed by Helene Hellmark Knutsson, who would as Minister of Research and Education become responsible for gender mainstreaming of higher education 2017-2019. ${ }^{13}$

Yet already in 2002 the Social-democratic government, in a writing to the parliament, committed to a clearly identity-political motivation for gender mainstreaming or similar measures when declaring that special measures are needed to increase female representation in society because women are subdued and dominated by men [48]. Based on a study of policy documents issued by the Swedish government, Madison ([5], p. 10) concluded that "these policy statements clearly convey an ambition to increase the proportion of women, to the effect that women have equal influence rather than merely equal opportunities to have influence", adding that "[t]hey are thus, in fact, strikingly consistent with

11 Judith Butler was interviewed about the Ringmar case in the Swedish magazine Kvartal [43]. Unhappy about the way in which her book was used in the particular case, she observes that "academic freedom recognizes the right of university teachers to conceive their courses in accordance with their own professional judgement" adding that she is "against attempts to force teachers to lecture on specific texts or authors" (our translation back to English).

12 A second factor that might make Vice Chancellors unwilling to oppose governmental policy is the relatively recent practice by the Ministry of Education and Research to appoint Vice Chancellors who are not affiliated with the university [46]. This has enabled some Vice Chancellors to be appointed consecutively at different universities, often in increasing academic standing, e.g., starting their career as Vice Chancellor at a regional university and ending it in the same position at one of the older universities in Lund or Uppsala.

13 The Deputy Director in question was in 2019 promoted Director of the Secretariat. 
the essence of the propositions that advocate quotas, biased treatment, and biased selection, which is to ... increase the proportion and influence of women, regardless of negative consequences."

Our negative findings regarding the academic outcome of gender mainstreaming is of course logically compatible with there being many positive academic effects of gender mainstreaming, such as increased chances for competent female scientists to pursue an academic career. However, an extensive recent study of publication metrics when attaining the rank of professor at the six largest universities in Sweden in the period 2009-2014 found that men had significantly more publications and citations in both medicine and the social sciences, indicating that Swedish academia was not systematically biased against women's research merits when gender mainstreaming was introduced in 2017 [49]. ${ }^{14}$

In fact, a case could be made that Sweden had by then already overcompensated for what is widely believed to be earlier discrimination against women in this regard. Thus, gender mainstreaming may have increased an already existing bias against men's research merits when hiring for the rank of professor, in which case the measures would not obviously be protected by aforementioned Article 41 in the UNESCO recommendations, which only allow for temporary measures aimed at accelerating de facto equality of disadvantaged members of the academic community, measures that should be "discontinued when the objectives of equality of opportunity have been achieved and systems are in place to ensure the continuance of equality of opportunity and treatment".

\section{Conclusions}

We found, first, that, while there was some variation in emphasis between universities, gender mainstreaming was introduced at Swedish universities in a version that was surprisingly radical in terms of its commitment to central identity-political ideas and claims when compared to the directives from the government in its decree from 2016. Moreover, the form of gender mainstreaming that was adopted by many universities seems to exclude biological perspectives on sex differences and hence potentially has a chilling effect on inquiry and speech regarding biological sex differences (the actuality of which was confirmed in one of our case studies). Second, gender mainstreaming was introduced "from above", through a special national unit placed by the government at one of the universities acting much like a Trojan horse in the academic system, in a way that posed a direct threat to the universities' institutional autonomy. As we observed, the higher education system in Sweden is particularly vulnerable to this kind of threat due to documented weaknesses in the organizational autonomy of Swedish universities. Lastly, we provided two case studies illustrating how gender mainstreaming, once in place, had negative effects on some scholars' freedom to teach. In particular, we observed that there is an obvious tension between the way the university in question acted in the two cases and the UNESCO articles protecting Lehrfreiheit. Our findings may be taken into account when evaluating the outcome of gender mainstreaming at Swedish universities all things considered.

Author Contributions: Both authors have made substantial contributions to all parts of the article in all stages, including conceptualization, method, empirical analysis, interpretation, editing and proofreading. Both authors have read and agreed to the published version of the manuscript.

Funding: No funding was received for this study.

Acknowledgments: The authors wish to thank the three viewers for their very valuable comments and suggestions on earlier versions.

Conflicts of Interest: The authors declare no conflict of interest.

14 The study found that males had $64-80 \%$ more scientific publications that had attained $42-260 \%$ more citations, resulting in a $72-83 \%$ larger h-index ([49], p. 13). 


\section{References}

1. UNESCO. Recommendations Concerning the Status of Higher-Education Teaching Personnel. Available online: http://portal.unesco.org/en/ev.php-URL_ID=13144\&URL_DO=DO_TOPIC\&URL_SECTION=201. html (accessed on 1 November 2020).

2. Jordansson, B.; Peterson, H. Jämställdhetsintegrering vid svenska universitet och högskolor. Det politiska uppdraget återspeglat i lärosätenas planer. Kvind. Køn Forsk. 2019, 48, 58-70. [CrossRef]

3. Arpi, I.; Wyndhamn, A.-K. Genusdoktrinen; Fri Tanke Förlag: Stockholm, Sweden, 2020.

4. World Economic Forum. The Global Gender Gap Report; World Economic Forum: Geneva, Switzerland, 2015.

5. Madison, G. Explicating Politicians' Arguments for Sex Quotas in Sweden: Increasing Power and Influence Rather Than Increasing Quality and Productivity. Front. Commun. 2019, 4, 1-12. [CrossRef]

6. Metzger, W. Academic tenure in America: A historical essay. In Faculty Tenure: A Report and Recommendations; Keast, W.R., Macy, J.W., Eds.; Jossey-Bass Publishers: San Francisco, CA, USA, 1973; pp. 93-159.

7. Karran, T. Academic freedom: In justification of a universal ideal. Stud. High. Educ. 2009, 34, $263-283$. [CrossRef]

8. Zagorin, P. How the Idea of Religious Toleration Came to the West; Princeton University Press: Princeton, NJ, USA, 2003.

9. Foucault, M. The Courage of Truth-The Government of Self and Others. Lectures at the Collége de France 1983-1984; Palgrave Macmillan: London, UK, 2012.

10. Connolly, J.M. The academy's freedom, the academy's burden. Though Action 2000, 16, 69-82.

11. Neave, G. On being economical with university autonomy: Being an account of the retrospective joys of a written constitution. In Academic Freedom and Responsibility; Tight, M., Ed.; Buckingham Open University Press: London, UK, 1998; pp. 31-48.

12. Sörensen, J.S.; Olsson, E.J. Academic Freedom and Its Enemies: Lessons from Sweden. In Knowledge for Justice: Critical Perspectives from Southern African-Nordic Research Partnerships; Halvorsen, T., Ibsen, H., Evans, H.-C., Penderis, S., Eds.; African Minds: Cape Town, South Africa, 2017; pp. 57-70.

13. Heyes, C. Identity Politics In The Stanford Encyclopedia of Philosophy. Available online: https://plato. stanford.edu/archives/fall2020/entries/identity-politics (accessed on 1 September 2020).

14. Taylor, C. Sources of the Self; Harvard University Press: Cambridge, UK, 1989.

15. Rose, N. Assembling the Modern Self. In Rewriting the Self: Histories from the Renaissance to the Present; Roy, P., Ed.; Routledge: London, UK, 1997.

16. Fukuyama, F. Identity: The Demand for Dignity and the Struggle for Recognition; Profile Books: London, UK, 2018.

17. Available online: https://www.merriam-webster.com/dictionary/identity\%20politics (accessed on 7 October 2019).

18. Oliver, T. Here's a Better Way to Think of Identity Politics. 2018. Available online: https://www.independent.co. uk/voices/identity-politics-how-lgbt-race- religion-social-background-football-team-a8419036.html (accessed on 1 November 2020).

19. Rawls, J. A Theory of Justice; Harvard University Press: Cambridge, MA, USA, 1971.

20. Östberg, K. I Takt Med Tiden: Olof Palme 1927-1969; Leopard Förlag: Stockholm, Sweden, 2010.

21. Andersen, M.; Collins, P.H. Race, Class and Gender, 10th ed.; Cengage Learning: Boston, MA, USA, 2019.

22. Walby, S. Gender Mainstreaming: Productive Tensions in Theory and Practice. Soc. Politics 2005, 12, 321-334. [CrossRef]

23. Morley, L. Sister-matic: Gender mainstreaming in higher education. Teach. High. Educ. 2007, 12, 607-620. [CrossRef]

24. Bacchi, C. Challenging the Displacement of Affirmative Action by Gender Mainstreaming. Asian J. Women's Stud. 2009, 15, 7-29. [CrossRef]

25. Council of Europe. Gender Mainstreaming: Conceptual Framework, Methodology and Presentation of Good Practices; Council of Europe: Strasbourg, France, 1998.

26. Commonwealth Secretariat. Gender Management System (GMS) Series; Commonwealth Secretariat: London, UK, 1999.

27. UNDP. Gender Mainstreaming: Learning and Development Pack; UNDP: New York, NY, USA, 2002.

28. UNESCO. Mainstreaming the Needs of Women; UNESCO: Paris, France, 2002.

29. Bureau for Gender Equality. Gender! A Partnership of Equals (Approaching Gender Issues); International Labour Organization, ILO: Geneva, Switzerland, 2000. 
30. Charlesworth, H. Not waving but drowning: Gender mainstreaming and human rights in the United Nations. Harv. Hum. Rights J. 2005, 18, 1-18.

31. Regleringsbrev för Budgetåret 2016 Avseende Universitet och Högskolor. 2015. Available online: https: //www.esv.se/statsliggaren/regleringsbrev/?RBID=17189 (accessed on 1 November 2020).

32. Available online: https://www.regeringen.se/pressmeddelanden/2015/09/regeringen-satsar-pajamstalldhetsintegrering-i-universitet-och-hogskolor/ (accessed on 10 August 2020).

33. Available online: https://genus.gu.se/english/about (accessed on 10 August 2020).

34. Swedish Secretariat for Gender Research 2016. Vägledning för Jämställdhetsintegrering av Högskolor och Universitet, Jämställd Akademi 2016:1. Available online: https://www.jamstall.nu/wp-content/uploads/2016/ 10/Vagledning-for-jamstalldhetsintegrering-av-hogskolor-och-universitet.pdf (accessed on 12 August 2020).

35. Svenell, A. Nära att dö—Vad Hände Med Jordan B Peterson; Svenska Dagblade: Stockholm, Sweden, 2020.

36. "Handlingsplan för Jämställdhetsintegrering 2017-2019" (Dnr. LED 1.3-2016/33). Available online: http://www.genus.se/wp-content/uploads/Malmo-hogskolas-plan-for-jamstalldhetsintegrering-20172019.pdf (accessed on 1 November 2020).

37. "Plan Concerning Gender Mainstreaming at Lund University, 2017-2019" (Reg. no STYR 2016/466). Available online: https://www.staff.lu.se/sites/staff.lu.se/files/plan_concerning_gender_mainstreaming_at_ lund_university_2017-2019.pdf (accessed on 12 August 2020).

38. Schmitt, D.P.; Long, A.E.; McPhearson, A.; O’Brien, K.; Remmert, B.; Shah, S.H. Personality and gender differences in global perspective. Int. J. Psychol. 2016, 52, 45-56. [CrossRef] [PubMed]

39. Stoet, G.; Geary, D.C. The Gender-Equality Paradox in Science, Technology, Engineering, and Mathematics Education. Psychol. Sci. 2018, 29, 581-593. [CrossRef] [PubMed]

40. Halpern, D.F.; Benbow, C.P.; Geary, D.C.; Gur, R.C.; Hyde, J.S.; Gernsbacher, M.A. The Science of Sex Differences in Science and Mathematics. Psychol. Sci. Public Interest 2007, 8, 1-51. [CrossRef] [PubMed]

41. Available online: https://academicrightswatch.com/?p=2871 (accessed on 12 August 2020).

42. Available online: https://academicrightswatch.com/?p=2846 (accessed on 1 November 2020).

43. Lindberg, M.T. Judith Butler om Genuskonflikten i Lund. 2017. Available online: https://kvartal.se/artiklar/ judith-butler-om-genuskonflikten-i-lund-metoden-ar-forkastlig/ (accessed on 1 November 2020).

44. Ch.2 in The Higher Education Ordinance (Högskoleförordningen). Available online: https://www.uhr. se/en/start/laws-and-regulations/Laws-and-regulations/The-Higher-Education-Ordinance/ (accessed on 1 November 2020).

45. Available online: https://www.university-autonomy.eu/ (accessed on 10 August 2020).

46. Olsson, E.J.; Sörensen, J.S.; Zetterholm, M. En Rektor ska Inte Vara en Ryggradslös Marionette; Svenska Dagbladet: Stockholm, Sweden, 2018.

47. Karran, T.; Beiter, K.; Appiagyei-Atua, K. Measuring academic freedom in Europe: A criterion referenced approach. Policy Rev. High. Educ. 2017, 1, 209-239. [CrossRef]

48. “Jämt och Ständigt: Regeringens Jämställdhetspolitik och Handlingsplan för Mandatperioden". Swedish Government. Available online: https://www.regeringen.se/rattsliga-dokument/skrivelse/2003/05/skr200203140/ (accessed on 1 November 2020).

49. Madison, G.; Fahlman, P. Sex differences in the number of scientific publications and citations when attaining the rank of professor in Sweden. Stud. High. Educ. 2020, 1-22. [CrossRef]

Publisher's Note: MDPI stays neutral with regard to jurisdictional claims in published maps and institutional affiliations.

(C) 2020 by the authors. Licensee MDPI, Basel, Switzerland. This article is an open access article distributed under the terms and conditions of the Creative Commons Attribution (CC BY) license (http://creativecommons.org/licenses/by/4.0/). 